\title{
Clarification of pineapple juice by microfiltration
}

\author{
Clarificação de suco de abacaxi por microfiltração
}

\author{
Lucia Maria Jaeger de CARVALHO ${ }^{1 *}$, Carlos Alberto Bento da SILVA²
}

\begin{abstract}
In the present work, pineapple juice was first hydrolyzed with a commercial pectinase (Ultrazym $100 \mathrm{G}$ ) and then clarified by microfiltration. A tubular polyethersulfone membrane with an average cut-off of $0.3 \mu \mathrm{m}$ and a total effective filtration area of $0.05 \mathrm{~m}^{2}$ was applied. The transmembrane pressures were 1.5 and $3.0 \mathrm{bar}$, respectively, and the processes was conducted at room temperature. The results showed that the pineapple juice permeate fluxes were of $57.77 \mathrm{~L} / \mathrm{m}^{2} /$ hours $\left(1.5 \mathrm{bar}\right.$ ) and $46.85 \mathrm{~L} / \mathrm{m}^{2} /$ hours $(3.0 \mathrm{bar})$. Concentration polarization and possibly fouling occurred during the processes. The best clarified juice fluxes were obtained when low transmembrane pressures (1.5 bar) were applied.

Keywords: fruit juice; enzymatic hydrolysis; membrane processes.
\end{abstract}

\section{Resumo}

No presente trabalho, suco de abacaxi foi inicialmente hidrolisado com enzima comercial (Ultrazym $100 \mathrm{G}$ ) e clarificado por microlfitração. Utilizou-se membrana tubular de polietersulfona com tamanho médio de poro de $0,3 \mu \mathrm{m}$ e área total de filtração de $0,05 \mathrm{~m}^{2}$. Foram aplicadas pressões de transmembrana de 1,5 e 3,0 bar, respectivamente, e os processos foram conduzidos à temperatura ambiente. Os resultados revelaram que os fluxos de suco permeado foram de $57,77 \mathrm{~L} / \mathrm{m}^{2} /$ horas $\left(1,5\right.$ bar) e $46,85 \mathrm{~L} / \mathrm{m}^{2} /$ horas $(3,0$ bar). O fenômeno de polarização de concentração e o fouling foram observados durante os processos. Os melhores fluxos de suco clarificado foram obtidos utilizando-se a pressão de transmembrana menos elevada (1,5 bar).

Palavras-chave: suco de fruta; hidrólise enzimática; processos com membranas.

\section{Introduction}

The conventional fruit juices clarification process involves several steps to obtain a limpid juice. On the other hand, tangential filtration or crossflow filtration such as Microfiltration (MF) and Ultrafiltration (UF) can substitute this process. Microporous membranes of different materials, configuration, and cut-off (pore size) can be used. The feeding solution is applied in parallel to the membrane surface, and pressure is the principal driving force.

These processes have many advantages such as the possibility of operating at room temperature and, in addition, promoting cold commercial sterilization (CARVALHO et al., 2002, 2003; GIRARDI; FUKUMOTO, 2000; DRIOLI; ROMANO, 2004; YOUN et al., 2004). The limiting factors that affect tangential filtration are concentration polarization and the fouling that occur during the process (GEHLERT; LUQUE; BELFORT, 1998; JIRARATANANON; UTTAPAP; TANGAMORNSIKSUN, 1997; RIEDL et al., 1996; TODISCO et al., 1996; LOSANO et al., 1996; KIM; HUR; CHOI, 1995; FANE, 1994; SU; LIU; WILEY, 1993; PADILLA-ZACOUR; MCLELLAN, 1989; SAURA et al., 1991; ITOUA-GASSAYE et al., 1991; CARNEIRO et al., 2002; VLADISAVLJEVI; VUKOSAVLJEVI; BUKVI, 2003; LÓPEZ et al., 2005; CASSANO; MARCHIO; DRIOLI, 2007; CASSANO et al., 2008). To minimize these problems, the enzymatic hydrolysis is recommended by many authors as a pretreatment for membrane processes (VAILLANT et al., 2001; PELEGRINE; VIDAL; GASPARETTO, 2000; TODISCO et al, 1996; PADILLA-ZACOUR; McLELLAN, 1993; HERNANDEZ et al., 1992; STUTZ, 1993; HASHIZUME; LATTIMER, 1974).

However, the use of certain enzymes such as lacase can confer negative characteristics such as turbidity increase (GOKMEN; BORNEMAN; NIJHUIS, 1998; STUTZ, 1993) after membrane processes. The UF and MF processes are used in juice clarification, but there are still unexplored clusters in the consumer market that can absorb them. Many authors have been studying the nutritional and sensorial characteristics as well as the microbiological quality of the juices before and after enzymatic hydrolysis (CARVALHO et al., 2006, CARVALHO; SILVA; PIERUCCI, 1998; JUAREZ; PAREDES-LOPEZ, 1994; MIETTON-PEUCHOT et al., 1990; PADILLA-ZACOUR; MCLELLAN, 1989; DUXBURY, 1986; HEATHERBELL; SHORT; STRUBI, 1977; MICHAELS, 1981).

Many volatile compounds can be lost during the process or remain in the retentate juice as well as in the concentration polarization layer of the membrane surface (CARVALHO; SILVA; ABADIO, 2002; 2008; CHAO; WEN; FANG, 1992; ITOUA-GASSAYE et al., 1991; RAO et al., 1987). The removal

Recebido para publicação em 16/12/2008

Aceito para publicação em 16/5/2009 (004000)

Departamento de Produtos Naturais, Faculdade de Farmácia, Universidade Federal do Rio de Janeiro - UFRJ, CEP 2054-110, Rio de Janeiro - RJ, Brasil,

E-mail: luciajaeger@gmail.com

${ }^{2}$ Curso de Nutrição, Centro Universitário de Barra Mansa - UBM, Barra Mansa - RJ, Brasil

${ }^{*}$ A quem a correspondência deve ser enviada 
of compounds responsible for turbidity, such as starch, pectin, tannins (responsible for juice astringency) and others by UF/ MF still promotes nutrients decrease in the permeated juices. Losses are normally verified according to the membrane cut-off and material, temperature, and transmembrane pressure. The purpose of this paper was to investigate the medium flux behavior of hydrolyzed pineapple juice using a $0.3 \mu \mathrm{m}$ microfiltration polyethersulfone membrane in a tubular system.

\section{Materials and methods}

Pineapple (Ananas comosus L. Merril cv. Pearl) cultivated in the city of São Francisco de Itabapoama, Campos, in the State of Rio de Janeiro was used in this experiment.

The pasteurized pineapple juice was processed at CETECFood \& Beverages, Vassouras, State of Rio de Janeiro. The crown was removed manually. The fruit was dipped in chlorinated water (15 ppm) for 10 minutes to remove dirtiness. The peeling was performed using previously cleaned steel knives, and the blanching was carried out in a crusher (Alfa Laval - Richmond, USA). The enzymatic inactivation (blanching) was performed at $85-90{ }^{\circ} \mathrm{C}$ for 2 minutes and the juice was filtered through sieves of 28; 20; 0.149, and $0.059 \mathrm{~mm}$ (Alfa Laval - finisher). Pasteurization was carried out at $85^{\circ} \mathrm{C}$ for 2 minutes (retention time) and cooled at $45^{\circ} \mathrm{C}$. The juice was packed in $50 ; 5.0 ; 1.0$, and $0.5 \mathrm{~L}$ PVC containers and stored at $-20^{\circ} \mathrm{C}$.

The final yield of the pasteurized juice was calculated by the difference between the weight of the whole fruit (crown and peel) before the process and the weight of the final juice obtained.

Preliminary tests with 100 ppm of Ultrazym $100 \mathrm{G}$, a commercial pectinase from Novozymes (Zurich, Switzerland), for 30 minutes at $40^{\circ} \mathrm{C}$ under constant shaking $(100 \mathrm{rpm})$ and using Ultrazym $100 \mathrm{G}$ (100 ppm/30 minutes) combined with $0.5 \%$ of Celluclast enzyme were performed to choose the best viscosity reduction (Tables 1 and 2).

Table 1. Viscosity $\left(30^{\circ} \mathrm{C}\right)$ of pasteurized pineapple juice and after enzymatic hydrolysis with Ultrazym $100 \mathrm{G}$.

\begin{tabular}{ccc}
\hline Sample & $\begin{array}{c}\text { Viscosity } \\
\text { (mPa/second) }\end{array}$ & $\begin{array}{c}\text { Viscosity decrease } \\
(\%)\end{array}$ \\
\hline Pasteurized juice & 9.5 & - \\
30` $100 \mathrm{ppm}$ & 6.7 & 27.6 \\
30`300 ppm & 7.4 & 22.1 \\
$90 ` 100 \mathrm{ppm}$ & 7.3 & 23.1 \\
$99^{`} 300 \mathrm{ppm}$ & 8.8 & 7.5 \\
$75 ` 200 \mathrm{ppm}$ & 9.2 & 1.5 \\
\hline
\end{tabular}

Table 2. Viscosity $\left(30^{\circ} \mathrm{C}\right)$ of pasteurized pineapple juice and after enzymatic hydrolysis with Ultrazym $100 \mathrm{G}+$ Celluclast.

\begin{tabular}{ccc}
\hline Sample & $\begin{array}{c}\text { Viscosity } \\
(\mathrm{mPa} / \text { second })\end{array}$ & $\begin{array}{c}\text { Viscosity decrease } \\
(\%)\end{array}$ \\
\hline Pasteurized juice & 9.5 & - \\
30` 100 ppm & 7.5 & 21.1 \\
30`300 ppm & 8.0 & 15.3 \\
$90 ` 100 \mathrm{ppm}$ & 7.7 & 19.2 \\
$90 ` 300 \mathrm{ppm}$ & 8.9 & 6.3 \\
$75 ` 200 \mathrm{ppm}$ & 9.1 & 3.8 \\
\hline
\end{tabular}

The enzymatic hydrolysis of the pasteurized pineapple juice was carried out for each process to obtain enough mass once the feeding tank maximum capacity is $25 \mathrm{~L}$.

An Armfield-multipurpose processing vessel Model-FF 40 (Armfield, Jackson, New Jersey, USA) homogenizer tank with juice at $40{ }^{\circ} \mathrm{C}$ was used under shaking, to which $100 \mathrm{ppm}$ Ultrazym $100 \mathrm{G}$ was added for 30 minutes. Next, the juice was frozen and stored at $-20{ }^{\circ} \mathrm{C}$.

The $20 \mathrm{~L}$ stainless steel vessels and the tank used for hydrolysis were first washed and sanitized with $\mathrm{NaOH}$ at $20 \%$, chlorinated water at $200 \mathrm{ppm}$ for 10 minutes, and rinsed with industrial water at $3 \mathrm{ppm}$.

The particle size reduction evaluation and its frequency were obtained by laser diffraction and reflection optical method in a particle analyzer (model Analysette 22, Fritsch $\mathrm{GmbH}$, Klar-Oberstein, Germany). This method was used to verify the pasteurized pineapple juice particle reduction after hydrolysis. All experiments were performed in quadruplicate.

Before each alkaline/acid/alkaline microfiltration process, cleaning steps were applied to recover the membrane water flux. Distilled water was recirculated into the system to remove pulp and residues. Next, a chlorine-alkaline solution $1 \%(\mathrm{pH}=11)$ at $45{ }^{\circ} \mathrm{C}$ for 30 minutes and 1.5 bar transmembrane pressure was recirculated in the membrane system until rescovering of the initial water permeability The membrane was disinfected with hydrogen peroxide $1 \%$ followed by distilled water plus $1 \%$ formic aldehyde washing. At the end of the washing process, distilled water was applied again.

A tubular membrane (Koch Membrane Systems,Wichita, USA) with $0.3 \mu \mathrm{m}$ pore size (polyethersulfone) and the effective filtration area of $0.05 \mathrm{~m}^{2}$ in a pilot system were used. Transmembrane pressures of 1.5 and 3.0 bar were applied and the processes were conducted at room temperature $\left( \pm 25^{\circ} \mathrm{C}\right)$. Five microfiltration experiments in the pilot system were conducted for each transmembrane pressure applied in the same operational conditions.

The membrane water flux was obtained at room temperature $\left(22-24^{\circ} \mathrm{C}\right)$, at which the time (seconds) was measured in relation to the water volume $(\mathrm{mL})$. The water fluxes were measured by $\mathrm{J}=\mathrm{V} / \mathrm{a}$. $\mathrm{t}$, where: $\mathrm{J}=$ permeate flux; $\mathrm{V}=$ volume of permeate water $(\mathrm{L}) ; \mathrm{a}=$ membrane area $\left(0.05 \mathrm{~m}^{2}\right)$; and $\mathrm{t}=$ time (hours).

Five experiments of each trasmembrane pressures (1.5 and 3.0 bar) were conducted at $\pm 25^{\circ} \mathrm{C}$.

The color instrumental analysis was performed using the S\&M Color Computer-SM-4-CH from Suga, USA, in the Hunter System. The color parameters in relation to Petri plate were L, a, b, $\Delta \mathrm{E}$, and turbidity (haze).

\section{Results and discussion}

From $1840 \mathrm{~kg}$ of pineapple, $611 \mathrm{~kg}$ of juice were obtained. The juice yield was about $33.22 \%$ over the raw material, as follows: 
- "In natura" gross weight $=1840 \mathrm{~kg}$;

- Post fruit peeling net weight $=1262 \mathrm{~kg}$; and

- Pineapple juice weight $=611 \mathrm{~kg}$.

The first trial (Table 1) was chosen due to its better juice reduced viscosity $(27.6 \%)$ and also to reduce costs with the enzymes.

The comparison between pasteurized and the hydrolyzed juice particle size reduction showed that there was more than $50 \%$ particle size reduction in the hydrolyzed pineapple juice.

In the pasteurized pineapple juice the particles size ranged from 0.16 to $0.32 \mu$, and the ones with 0.22 and 0.32 presented high frequency when compared with the particle size of the hydrolyzed juice, in which the high frequency ranged from 0.16 to $0.22 \mu \mathrm{m}$. The statistical results showed $6.163 \%$ Coefficient of Variation (VC), 16.113\% Standard Deviation (SD), 8.25\% (VC), and $12.113 \%$ (SD) for the hydrolyzed pineapple juices, respectively.

The mean fluxes of $3109.70 ; 4255.32$, and $5341.25 \mathrm{~L} / \mathrm{m}^{2} /$ hours were obtained with the $0.3 \mu \mathrm{m}$ membrane at $1.5,2.0$ and 2.5 bar, respectively. After each process, it was observed that there was a decrease in the membrane permeability, which was restored after the cleaning procedure (Figure 1).

From $18 \mathrm{~L}$ of hydrolyzed pineapple juice used as feeding, 11.25 L of permeate juice and $6.75 \mathrm{~L}$ of retentate were obtained after 3 hours of process. The permeate juice recovery was about $62.5 \%$ and the volumetric concentration was 2.6 . The medium flux after the process was $57.55 \mathrm{~L} / \mathrm{m}^{2} /$ hours (Figure 2).

From $14.5 \mathrm{~L}$ of hydrolyzed pineapple juice used as the feeding system, $9.35 \mathrm{~L}$ of permeated and $5.15 \mathrm{~L}$ of retentate juice were obtained, which corresponds to $64.48 \%$ of recovery. The volumetric concentration was 2.8 . The medium flux after 4 hours was $46.85 \mathrm{~L} / \mathrm{m}^{2} /$ hours (Figure 2 ). The medium flux obtained with $0.3 \mu \mathrm{m}$ operated at 3.0 bar was lower than that obtained when the system was operated at 1.5 bar. However, an increase in the flux was observed after 2.5 hours. The juice recirculation into the membrane system might have promoted (a self-cleaning effect at membrane surface level increasing the permeate flux. Chamchong and Noomhorm (1991) verified an increase in the flux with the increase in the membrane cut-off.

On the other hand, Tarlerton and Walkeman (1993) observed that there is little membrane cut-off influence on the flux as well as on the macromolecules rejection when most of the feeding particles are higher than the membrane cut-off and the permeate quality. The flux is normally lower when most of the particles have molecular weight value close the membrane cut-off.

According to Riedl, Lencki and Girard (1996), the polysulfone and nylon membranes promote more resistance to concentration polarization than that promoted by polyethersulfone and polyvinylidene fluoride membranes. The drastic reduction of particles size caused by enzymatic hydrolysis can promote a flux decline on permeate juice because of pore obstruction (fouling).
Lenggenhager and Lyndon (1998) also observed juice concentration polarization during clarification with polysulfone, polyethersulfone, and polyvinylidene fluoride membranes. However, Gehlert, Luque and Belfort (1998) found that tubular polyethersulfone membrane promotes the highest fluxes.

According to Youn et al. (2004) polysacharides, proteins and colloidal materials are present as solid materials in juices, which form crystal with the increment of concentration polarization or become a gel layer which, in turn, accumulates on the surface to form a secondary membrane as the filtration goes on. The solute adsorption inside and/or on the membrane may change the MWCO membrane characteristics increasing the membrane resistance

A slight decrease in luminosity was observed for the pasteurized (12.9) and hydrolyzed (13.6) pineapple juices. The highest turbidity was observed in the hydrolyzed juice (97.5), probably due to the increased number of particles in suspension after hydrolysis. As expected, the luminosity of the permeate juice increased and the turbidity was almost completely removed (Table 3).

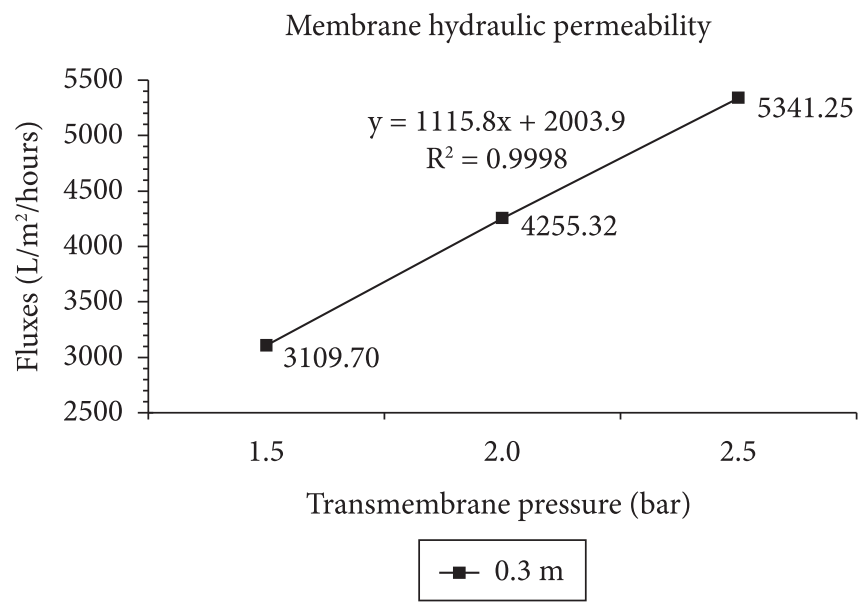

Figure 1. Hydraulic permeability of $0.3 \mu$ polyethersulfone tubular membrane at various transmembrane pressures.

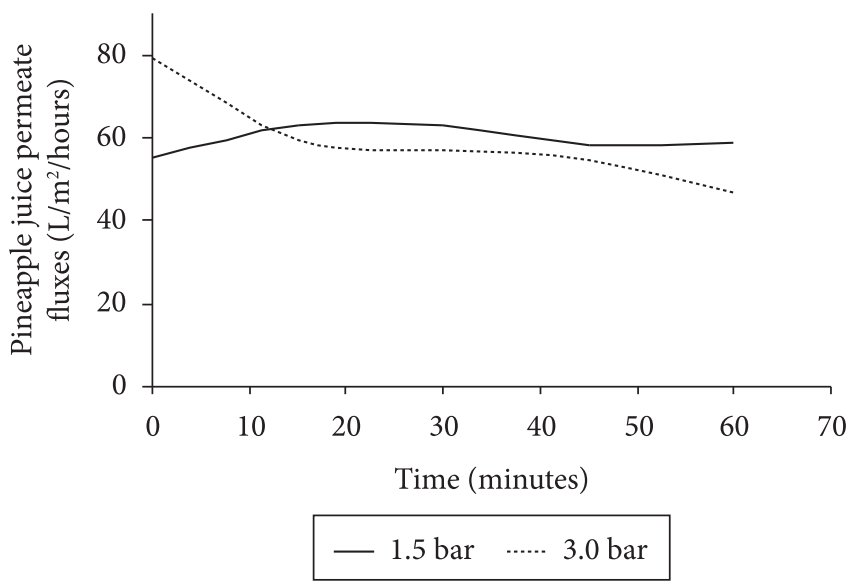

Figure 2. Pineapple juice fluxes at 1.5 and 3.0 bar. 
Table 3. Pasteurized, hydrolyzed and permeated pineapple juices instrumental color, in relation to Petri plate.

\begin{tabular}{|c|c|c|c|c|c|}
\hline Sample & $\begin{array}{l}\text { TMP } \\
\text { (bar) }\end{array}$ & $\begin{array}{c}\text { Luminosity } \\
\left(\mathrm{L}_{\text {Hunter }}\right)\end{array}$ & $\mathrm{a}_{\text {Hunter }}$ & $\mathrm{b}_{\text {Hunter }}$ & Haze \\
\hline Pasteurized juice & - & 12.9 & 0.2 & 6.7 & 97.3 \\
\hline Hydrolyzed juice (feed) & - & 13.6 & 0.1 & 6.9 & 97.5 \\
\hline $0.3 \mu$ & 1.5 & 97.9 & -2.0 & 11.9 & 3.1 \\
\hline $0.3 \mu$ & 3.0 & 98.7 & -2.2 & 11.3 & 1.9 \\
\hline
\end{tabular}

The luminosity was lower and, consequently, the turbidity of the permeated juice was higher, 1.5 bar (97.9 and 3.1, respectively), than when the system was operated at 3.0 bar (98.7 and 1.9, respectively) showing that the highest TMP (transmembrane pressures) promotes higher luminosity in the permeated juices.

Kim, Hur and Choi (1995) reported an increase of 90\% in luminosity and a decrease in turbidity of sugar cane juice clarified by UF membranes.

\section{Conclusions}

The clarification of the pineapple juice by MF in a $0.3 \mu \mathrm{m}$ polyethersulfone membrane was more effective when $1.5 \mathrm{bar}$ TMP was applied, although concentration polarization and the fouling phenomenon occured during the process under both transmembrane pressures applied.

As expected, the luminosity of the permeate juice increased and the turbidity was almost completely removed.

\section{Acknowledgments}

The authors are grateful for the support provided by Carlos Chagas Research Foundation of Rio de Janeiro State - FAPERJ; José Bonifácio Foundation (FUJB/UFRJ); Coca-Cola; R \& D Center, Rio de Janeiro; CETEC Food and Beverages, Rio de Janeiro; EMBRAPA Food Technology, Rio de Janeiro; and Novozymes, Switzerland.

\section{References}

CARNEIRO, L. et al. Cold sterilization and clarification of pineapple juice by tangential microfiltration. Desalination, v. 148, n. 1-3, p. $93-98,2002$.

CARVAlHO, L. M. J.; SILVA, C. A. B.; PIERUCCI, A. P. T. R. Clarification of pineapple juice (Ananas comosus L. Merril) by ultrafiltration and microfiltration: physicochemical evaluation of clarified juices, soft drink formulation and sensorial evaluation. Journal of Agricultural Food Chemistry, v. 46, n. 6, p. 2185-2189, 1998.

CARVALHO, L. M. J. et al. Commercial sterilization of fruit juices UF and MF membranes. Alimentaria: Revista de Tecnologia e Higiene de los Alimentos, v. 333, p. 123-129, 2002.

CARVAlHO, L. M. J.; SILVA, C. A. B.; ABADIO, F. D. B. Volatile compounds in hydrolyzed pineapple (Ananas comosus L. Merril) Pérola variety and clarified pasteurized juices obtained by SPME.
Alimentaria: Revista de Tecnologia e Higiene de los Alimentos, v. 333, p. 129-132, 2002.

CARVALHO, L. M. J. et al. Identifying the adequate process conditions by consumers for the pineapple juice using membrane technology. Journal of Food Technology, v. 1, n. 4, p.150-156, 2003.

CARVALHO, L. M. J. et al. Effect of enzymatic hydrolysis on particle size reduction in lemon juice (Citrus limon, L.), cv. Tahiti. Brazilian Journal of Food Technology, v. 4, n. 9, p. 277-282, 2006.

CARVAlHO, L. M. J.; CASTRO, I. M.; SILVA, C. A. B. A study of retention of sugars in the process of clarification of pineapple juice (Ananas comosus, L. Merril) y micro and ultrafiltration. Journal of Food Engineering, v. 87, p. 447-454, 2008.

CASSANO, A. et al. Recovery of bioactive compounds in kiwi fruit by ultrafiltration. Innovative Food Science and Emerging Technologies, v. 9, n. 4, p. 556-562, 2008.

CASSANO, A.; MARCHIO, M.; DRIOLI, E. Clarification of blood orange juice by microfiltration: analyses of operating parameters, membrane fouling and juice quality. Desalination, v. 212, n. 1-3, p. 15-27, 2007.

CHAMCHONG, M.; NOOMHORM, A. Effect of enzymatic treatment on microfiltration and ultrafiltration of tangerine juice. Journal of Food Processing Engineering, v. 14, n. 1, p. 21-24, 1991.

CHAO, H. W.; WEN, S. K.; FANG, T. T. Influência da ultrafiltração e da osmose reversa na qualidade do suco de maracujá (Passion fruit) concentrado. Journal Chinese Agricultural Chemistry Society, v. 30, n. 3, p. 413-431, 1992.

DRIOLI, E.; ROMANO, M. Progress and new perspectives on integrated membrane operations for sustainable industrial growth. Industrial Engineering and Chemistry Research, v. 40, n. 5, p. 1277-1300, 2001.

DUXBURY, D. D. Specialty pectinase enzyme increases juice yields 10-13\%. Food Processing, v. 47, n. 2, p.114, 2000.

FANE, A. G. Pressure-driven membrane process-microfiltration, ultrafiltration and reverse osmosis. In: LATIN AMERICAN SCHOOL ON MEMBRANE PROCESSES, 1., 1994, Rio de Janeiro. Anais...

GEHLERT, G; LUQUE, S.; BELFORT, G. Comparison of ultra-and microfiltration in the presence and absence of secondary flux with polysaccharides, proteins, and yeasts suspensions. Biotechnology Progress, v. 14, n. 6, p. 931-942, 1998.

GIRARDI, B.; FUKUMOTO, L. R. Apple juice clarification using microfiltration and ultrafiltration polymeric membranes. Food Science and Technology-Lebensmittel Wissenschaft and Technologie, v. 32, n. 5, p. 290-298, 2000.

GOKMEN, V., BORNEMAN, Z.; NIJHUIS, H. Improved ultrafiltration for color reduction and stabilization of apple juice. Journal of Food Science, v. 63, n. 3, p. 504-507, 1998.

HASHIZUME, T.; LATTIMER, O. T. Utilização de ULTRAZYM 100 na clarificação de suco de uva. Coletânea do Instituto de Tecnologia de Alimentos, v. 5, p. 117-127, 1974.

HEATHERBELL, D. A.; SHORT, J. L.; STRUBI, P. Apple juice clarification by ultrafiltration. Confructa, v. 22, p. 157, 1977.

HERNANDEZ, E. et al. Ultrafiltration of orange juice: effect on soluble solids, suspended solids, and aroma. Journal of Agricultural and Food Chemistry, v. 40, n. 6, p. 986-988, 1992.

ITOUA-GASSAYE, S. et al., R. Résultats récents dans l'utilisation des techniques à membrane appliquées aux jus de fruits. In : Symposium of the Intern. Federation of Fruit Juice Producers XXI, Paris, France, 16/18 May, 1990. 
ITOUA-GASSAYE, S. et al. Intéret des techniques à membrane dans la production de jus tropicaux (cas de jus clarifiés d'ananas) B Evolution des composants a caractére organoléptique au cour du procédé. Fruits, v. 46, n. 4, p. 453-459, 1991.

JIRARATANANON, D.; UTTAPAP, D.; TANGAMORNSIKSUN, C. Self-forming dynamic membrane for ultrafiltration of pineapple juice. Journal of Membrane Science, v. 129, n. 1, p. 135-143, 1997.

JUAREZ, M. S.; PAREDES-LOPEZ, O. Studies on jicama juice processing. Plants Foods for Human Nutrition, v. 46, n. 2, p. 127-131, 1994.

KIM, J. H.; HUR, S. S.; CHOI, Y. H. Studies on the efficient clarification process of apple juice with ultrafiltration process. Food and Biotechnology, v. 4, n. 2, p. 79-84, 1995.

LENGGENHAGER, T.; LYNDON, R. Profit generating benefits of ultrafiltration and adsorber technology. Fruit Processing, v. 7, p. 150-256, 1998.

LOPEZ, F. et al. Industrial vinegar clarification by cross-flow microfiltration: effect on colour and polyphenol content. Journal of Food Engineering, v. 68, n. 1, p. 133-136, 2005.

LOSANO, L. E. et al. Hollow fiber ultrafiltration of apple juice. Microscopic approach. Lebensmittel-WissenschaftundTechnologie, v. 30, n. 4, p. 373-378, 1996.

MICHAELS, A. S. Ultrafiltration: an adolescent technology. Chemtech, v. 62, n. 11, p. 36-46, 1981.

PADILLA-ZACOUR, O.; McLELLAN, M. R. Molecular weight cut-off of ultrafiltration membranes and the quality and stability of apple juice. Journal of Food Science, v. 54, n. 5, p. 1250-1254, 1989.

PADILLA-ZACOUR, O.; McLELLAN, M. R. Optimization and modeling of apple juice cross-flow microfiltration with ceramic membrane. Journal of Food Science, v. 58, n. 2, p. 369-388, 1993.

PELEGRINE, D. H.; VIDAL, J. R. M.; GASPARETTO, C. A. Estudo da viscosidade aparente das polpas de manga (Keitt) e abacaxi (Pérola). Ciência e Tecnologia de Alimentos, v. 20, n. 1, p. 128-131, 2000.

RAO, M. A. et al. Clarification of apple juice by hollow fiber ultrafiltration: fluxes and retention of odor-active volatiles. Journal of Food Science, v. 52, n. 2, p. 375-377, 1987.
RIEDL, K.; GIRARD, P.; LENCKI; R. W. Influence of membrane structure on fouling layer morphology during apple juice clarification. Journal of Membrane Science, v. 139, n. 2, 1996.

RIEDL, K. M.; LENCKI, R. W.; GIRARD, B. Effect of membrane and fouling layer morphology on permeate flux during apple juice microfiltration. Journal of Membrane Science, v. 139, p. 155-166, 1998.

SAURA, D. et al. Tangential flow filtration with enzymatic treatment in clarification of lemon juice. Mededelingen - Faculteit Landbouwwetenschappen, Rijksuniversiteit Gent, v. 56, p. 1705-1707, 1991.

STUTZ, C. The use of enzymes in ultrafiltration. Fruit Processing, v. 7, n. 3, p. 248-252, 1993.

SU, S. K.; LIU, J. C.; WILEY, R. C. Cross flow microfiltration with gas backwash of apple juice. Journal of Food Science, v. 58, n. 3, p. 638-641, 1993.

SZAJER, I.; SZAJER, C. Clarification of apple juice by pectin-lyase from Penicillium paxilli. Biotechnology Letters, v. 4, n. 9, p. 553-556, 1982

TARLERTON, E. S.; WALKEMAN, R. J. Understanding flux decline in crossflow microfiltration: Part I - Effects of particles and pore size. Chemical Engineering Research and Design, v. 71, p. 399-409, 1993.

TODISCO, S. et al. Analysis of the fouling mechanism in microfiltration of orange juice. Journal of Food Processing and Preservation, v. 20, n. 6, p. 453-466, 1996.

VAILLANT, F. et al. Strategy for economical optimization of the clarification of pulpy fruit juices using crossflow filtration. Journal of Food Engineering, v. 48, n. 1, p. 83-90, 2001.

VLADISAVlJEVI, G. T.; VUKOSAVLJEVI, P.; BUKVI, B. Permeate flux and fouling resistance in ultrafiltration of depectinized apple juice using ceramic membranes. Journal of Food Engineering, v. 60, n. 3 , p. $241-247,2003$.

YOUN, K. S. et al. Effective clarifying process of reconstituted apple juice using membrane filtration with filter-aid pretreatment. Journal of Membrane Science, v. 228, n. 2, p. 179-186, 2004. 